The International Journal of Human Resource Management, Volume 19, Issue 11, November 2008, Pages 2024-2040

\title{
North American MNCs and their HR policies in liberal and co-ordinated market
}

\author{
economies
}

\begin{abstract}
We explore the landscape of HRM in North American MNCs which have been for long characterised as having an express preference for institutionalising aspects of the home business system when operating aboard. Drawing upon institutional theory, both the USA and Canada are identified as liberal market economies. Building on this, we examine the HR preferences of subsidiaries originating in North America and operating in diverse liberal and co-ordinated market economies in order to test the extent to which the host context influences the pattern of HR policies and practices pursued, referring predominantly to the literature on USA firms. The results indicate that the pattern of HR practices pursued by North American owned MNCs varies widely depending on whether these North American owned MNCs are operating in liberal or co-ordinated market economies, lending support to the importance of context as a determinant of the likelihood of, and limits to, the transfer of HRM practices and preferences.
\end{abstract}




\section{Introduction}

The management of employees on a global scale creates a unique set of organizational, coordination and managerial choices with respect to standardizing or localizing HR policy and practice (Tregaskis et al., 2000; Dickmann and Müller-Camen, 2006). In developing and implementing policies and practices, MNCs and their subsidiaries must seek a balance between the implementation of HRM practices that conform to the legitimate expectations and requirements of their host environment, or the pursuit of more distinctive practices in their foreign subsidiaries based on those employed at home or best practices learned from other sources (Gunnigle et al., 2001). The institutionalisation of specific HR practices is however impacted by a complex range of factors, not least the nature of the institutional environment in each host location. This paper seeks to determine whether the HR policies of North American owned MNCs operating in North America vary compared to those operating outside North America in the institutional environment of liberal market economies (LMEs) or co-ordinated market economies (CMEs).

Drawing upon Hall and Soskice's varieties of capitalism argument (2001) to distinguish liberal and co-ordinated market economies and employing 2003 Cranet data we assess the HR configurations of the subsidiaries of North American MNCs operating in liberal (UK and Australia) and co-ordinated (Denmark, Germany, Netherlands and Sweden) market economies. While the paper acknowledges that there are differences in the institutional context and HR practices of Canadian and USA MNCs, it will argue that there is much similarity of practices, underlying values and regulatory frameworks (Rosenzweig and Nohria, 1994; Block, 2006). Overall, our analysis casts further light on the likelihood of, and limits to, convergence in HR practices, and draws attention to the enduring tenets of 
contextual HR practices in situations where there is manifest institutional distance between the home and the host environment. First, however, we engage with the debate on the desirability and feasibility of the international transfer of HR policies and practices in order to explore why MNCs may want to retain consistent processes across overseas subsidiaries.

\section{Desirability of International Standardisation of HRM}

There are several reasons why MNCs may want to co-ordinate their HRM internationally and why they might want to transfer their parent practices to their subsidiaries abroad. Firstly, if a firm has a successful experience with specific HR approaches, it is likely to want to standardise them internationally if it judges these to be appropriate to the local environment (Dickmann and Müller-Camen, 2006). Key reasons for this approach could include economies of scale, higher quality of service and increased international coordination (Bartlett and Ghoshal, 1989). Internationally operating MNCs are likely to transfer their home HRM practices if they regard these practices as superior. Secondly, an ethical dimension may lead to the international standardisation of practices that are seen as legitimate in its country of origin or in another national jurisdiction in which the firm operates. Examples on this front might include the establishment of systems that guarantee workers' minimum rights and precludes child labour. Thirdly, MNCs may seek to integrate all policies around a specific set of HR policies and practices in order to support their wider business strategy (Schuler and Jackson, 1987; Dickmann, 2003). This may entail extensive employee development and involvement (Vitols et al., 1997). Fourthly, Bonache and Dickmann (2008, in press) argue that in settings where MNCs strive to establish certain quality standards, expatriates act as critical nodes in the firms international network and perform the role of knowledge transferors from the head office outwards leading to the 
potential for international standardisation of HRM (c.f. also Gupta and Godinvarajan, 2000; Morley \& Heraty, 2004). Thus, the actual transfer of HR and other approaches may be related to the reasons why MNCs operate in the country in the first place. The desirability of conformity around home country standards does not, however, mean that it is also always feasible. What operates successfully in one country may not be appropriate for another and, while importation of specific features of one system may occur, a blanket approach to the transposition appears limited (Morley et al., 1996). It is to this issue of feasibility that we now turn.

\section{Feasibility of Standardisation - Pressures for Localisation}

There may be endogenous factors that have an impact on the degree of standardisation of HR practices across borders (Geppert, Williams and Matten, 2003; Dickmann and Müller-Camen, 2006). Ferner and Edwards (1995) describe 'channels of influence' for organisational change such as control over power resources, authority structures, and organizational culture. Moreover, deeper trust between the corporate centre and the foreign operating unit supports practice transfer (Szulanski, 1996). Power dynamics influence the feasibility of standardisation (Birkinshaw and Fry, 1998), and if the internalisation of practices that feel 'alien' in the host environment is incomplete, the actual standardisation may be less than perfect and conformity may indeed decrease over time (Ferner et al., 2005). The relationship between head office and the foreign affiliate(s) is likely to impact on the degree to which practices are adopted at operational level (Kostova and Roth, 2002). Thus, if local management is able to resist the corporate centre, international integration is made more difficult. MNCs may either not be capable of forcing, or may not wish to force, their operating units abroad to take up certain parent approaches (Dickmann et al., in press 2009). 
DiMaggio and Powell (1991) argue that there may be coercive forces that may make it impossible to standardise HR policies across borders. For instance, normative barriers to international standardisation in the form of increasing professionalisation of occupations and their institutional bodies may exist. Market characteristics or work norms exert normative pressures for local isomorphism if their inherent values are distinct from those held abroad. For instance, the dominant market logic (consumer vs. producer logic), the diverse bases of remuneration, the power of management and its interaction with others are distinct in the USA compared to Germany or Japan (Pudelko, 2006). Thus, managers in these countries might resist the transfer of a USA remuneration approach in favour of more security-oriented compensation. Under conditions of institutional uncertainty it may be possible that local actors interpret and change the USA HR approaches to shape operational practices to suit their interests (Almond et al., 2005). In this respect a key factor that determines the feasibility of international transfer relates therefore to the compatibility of the business systems in question.

The debate regarding the international integration of business approaches has been an enduring feature of the international management literature for the last three decades and often distinguishes continued divergence or the process of directional or final convergence (Mayrhofer et al., 2002). There is still a substantial debate concerning the extent to which MNCs' "foreign affiliates (or subsidiaries) act and behave as local firms versus the extent to which their practices resemble those of the parent corporation or some other global standard" (Rosenzweig and Nohria, 1994: 229). It is often seen as a rather dichotomous debate with many contributors suggesting that the national context, and the institutionalisation that flows from it, is all important, while others contend that practices of this nature are not subject to 
the constraints of context and consequently MNCs have the ability to import practices at will and behave as free agents (Tregaskis et al., 2001). To explicate this argument on the context specific nature of the business system, and the potential for distance between such systems, we draw upon Hall and Soskice's (2001) framework which we discuss below.

\section{LMEs and CMEs: Diverging degrees of freedom and distinct HR bases}

In framing the above debate, the nature of the national business system is seen to be of high significance. Hall and Soskice (2001) argue that developed capitalist countries can be divided into 'liberal market economies' (LMEs) and 'co-ordinated market economies' (CMEs). LMEs, such as the USA, Canada, UK, or Australia are countries in which relations between firms are co-ordinated, primarily by competitive markets. On the other hand CMEs, such as Germany, Sweden, Denmark or the Netherlands are countries where firms typically engage in more strategic interaction with trade unions, suppliers of finance and other actors. Complementarities between external relations - such as relations with the government, banks, universities, industry bodies, trade unions and employer federations - are seen to develop over time, along with company approaches regarding employment relations, modes of investment activities or corporate governance (Whitley, 1999). Jacoby (2005) stresses that economic actors react to similar external pressures in different ways due to path dependencies. Because economic institutions in a state interact, the author argues that there may be continued divergence, even though the reaction to the pressures may aim at the same outcome. Jacoby likens it to rotary and diesel engines - the parts are different but the outcome of generating horsepower (or torque) is the same (2005: 17). 
Kostova (1999) has looked at the 'country institutional profile' (CIP) distinguishing regulatory, normative and cognitive institutions. Based on the extent of institutional distance' between countries, the feasibility of transfer of HR practices is seen to be impacted. The higher the institutional distance, the more difficulties a cross-national transfer of HR practices may entail. We may expect that the degree of localisation that occurs in MNCs is different according to whether the host country is an LME or CME and that the suite of dominant HR practices pursued will vary, depending on the institutional distance and the specific regulatory context. The various pressures which Kostova and Roth (2002) identify would indicate that the degrees of freedom not to conform to the predominant HR context are higher in LMEs than in CMEs.

This paper will examine the degree of transfer of HRM policies used within the context of an MNC's home country to a liberal market economy away from home and a coordinated market economy away from home. We have chosen to focus on North American MNCs due to their prevalence, so we will explore the degree to which HR policies are being transferred in North American MNCs located in LMEs and CMEs. Firstly however, we will establish the important features of HRM in North American MNCs and review past research on the transfer of these practices.

\section{HRM in North American Companies}

There is a long tradition of analysing American HRM (Guest, 1990) - mostly referring to North American HR policies and practices and, amongst those, concentrating on the USA. As some of the key ideas of HRM emerged from the United States (e.g. Fombrun et al., 1984; Beer et al., 1985), European commentators have analysed the differences between USA and 
European HRM (Ferner, 1997; Brewster et al., 2000; Brewster et al., 2004; Almond et al., 2005 ) - in fact, so much so, that voices have emerged warning that some of these differences may be exaggerated (Strauss, 2001). In an attempt at parsimony, we provide here only a brief summary of the defining features of the USA 'model' of HRM.

Key areas of distinctiveness of USA HRM include the emphasis on strategic HRM (Schuler and Jackson, 2005) and the handling of employment relations and communication on an individualised basis (Kalleberg et al., 1996). Distinctive USA HRM practices also include the use of sophisticated selection techniques in employee resourcing (Gunnigle et al., 2001), the pursuit of individualised, performance based rewards (Colling and Clark, 2002), a focus on training and development for the purposes of human capital accumulation (Giardini et al., 2005), and a strong emphasis on diversity management (Egan and Bendick, 2003). Due to the distinctiveness of the USA HRM model along these dimensions, and the attachment to a universalist paradigm with a "tacit conviction that there is a one-best-way of organising for efficiency" (Mayrhofer et al., 2000: 6), attempting to transfer preferred home approaches to overseas host locations offers the appealing prospect of using standardised HR practices.

\section{Transfer of USA HRM to Europe}

We will now examine past literature on the transfer of USA HRM practices to American MNCs based away from the USA. Case study research on the HR behaviour of USA MNCs abroad tends to focus on the reasons for international standardisation, organisational structures as well as the processes, power dimensions and outcomes over time (Ferner and Quintanilla, 1998; Singe and Croucher, 2005). For instance, with regards to the nature of the determination of HRM policy, Ferner et al. (2004) found that USA MNCs displayed 
centralised, standardised and formalised traits. With respect to the identified USA HR model aspects, some key studies looking at the HR behaviour of USA MNCs in Europe are outlined below.

In their study of foreign MNCs operating in Europe Gunnigle et al. (2001) found that although MNCs from both the USA and differing European countries modified their practices to account for the host context, levels of localisation in USA MNCs tended to be lower than other MNCs. Singe and Croucher (2005) found that USA-based companies abroad appear to formally comply with works council regulations and sectoral bargaining patterns in Germany. Their case studies, however, indicate that USA MNCs in Germany may practice works council avoidance and that they may put pressure on works councillors to distance themselves from trade unions. The authors conclude that these firms tend to explore all options available to them within the existing system.

Noble (1997) argues that while USA MNCs may be ethnocentric with regards to their competitive strategies, it is possible that they are polycentric in training and development. Egan and Bendick (2003) found that diversity principles were transferred but that local affiliates had the necessary degrees of freedom to adapt the diversity approach to the national and local context. Poutsma et al. (2005) looked at the international transfer of reward approaches within USA multinationals. They concentrated on share option schemes and found an Anglo-Saxonisation effect in continental Europe. While in the range of HR approaches there is evidence of Anglo-Saxonisation of USA MNCs' subsidiaries, there are also substantial institutional barriers to standardisation in CMEs (Müller, 1998; Geppert, Matten and Williams, 2003). 
Combined, the insights from these studies point to a complex picture of standardisation and localisation depending on the nature of the specific HR practice being explored and the institutional characteristics of the host location. However, few would argue that our knowledge of this complex aspect of operating internationally is complete. It is partial at best with the result that much more evidence on the possibility for, and the conditions under which, HRM transfer can occur is required. Garnering further evidence on this front is important and timely. It is an area in which complexity continues to increase as the diversity of host locations for FDI around the globe grows rapidly. Drawing upon institutional thinking, which is especially useful for landscaping the similarities and differences inherent in different countries' business systems and the resultant proximity or distance evident between countries, we explore this debate further.

\section{Research questions}

While a stylised USA 'model' of HRM has emerged from the above, it is important to move beyond a simplistic notion to understand the degree of these 'typical' HR strategies, policies and practices in reality. In our initial step, we explored the HR configurations of North American companies in LMEs and CMEs.

We acknowledge that the 'gestalt' of HRM in its institutional context varies somewhat between Canada and the USA, but for the purposes of our analysis, reasonable conceptual and empirical equivalence between both countries can be drawn on the HRM front. Conceptually, there is little doubt that Canada displays less extensive characteristics of liberal market economies than does the USA. For instance, the trade union density and presence within Canadian industry is higher than in the USA and the USA system is "less conducive to 
union membership than the Canadian system" (Block, 2006: 36). Other differences include variations in bargaining arrangements, dispute resolution machinery, economic regulation and constraints on capital and employment practices. Despite these differences, institutional provision springing from the industrial relations systems of both the USA and Canada has resulted in them being characterised as siblings in that they have "similar origins and reflect similar values" (Block, 2006: 25) and in the HR sphere, research does indicate a similarity between HR practice in USA and Canada (cf. Rosenzweig and Nohria, 1994). Furthermore, the Canadian economy is characterized by a very high presence of USA-based MNCs (Bélanger et al., 2006). In addition, Templer et al. (1997: 551) note that legislative impacts have "directed HR practice towards equality issues such as employment equity and pay equity".

Empirically, our argument on the equivalence between the USA and Canada on this front may also be defended. Using data from a previous Cranet survey we have run an analysis to examine the similarity of HRM in USA and Canadian MNCs and our results too point to few significant differences. More specifically we have compared USA and Canadian owned MNCs operating in a range of countries outside of North America on a number of dimensions relating to recruitment and selection, diversity, rewards, briefing strategy and training using the 1999 Cranet data. In each case, we found that the USA and Canadian owned MNCs were not significantly different. In this context, using North American owned MNCs, incorporating USA and Canadian owned together, as the wellspring for our analysis in this paper can therefore be justified.

We isolated the North American owned sub-sample, and explored whether the context in which these North American MNCs were operating resulted in a distinct pattern of HR 
policies and practices. We were guided by the above discussion on the dominant business system and its effects on MNCs' approach to HRM standardisation/localization to draw up the following research questions designed to explore whether the context in which these North American MNCs operate results in a distinctive pattern of HR policies and practices. The following two research questions guided our empirical effort.

1. Do North American owned MNCs outside of North America located within liberal market economies display different HR policies and practices to those located within co-ordinated market economies, and those located within North America itself?

2. If so, are North American owned MNCs in LMEs more similar to North American MNCs in North America than to North American MNCs in CMEs?

We have explored above that there is a strong stream of literature which argues that North American originating MNC subsidiaries seek to institutionalise characteristics of their home business system or "country of origin" in the management of their foreign subsidiaries. We now propose to further test whether this is the case in our sample and whether the national business system context, namely liberal or co-ordinated economy, has explanatory power in accounting for the degree of standardisation or localisation evident in our sample.

\section{Method}

\section{Data}

The data used in this study were taken from the 2003 Cranet survey, by far the most comprehensive international survey of HR policies and practices at the organisational level. Cranet is a regular comparative survey of organisational policies and practices across the 
world conducted by a network of business schools operating in 40 countries (see Brewster et al., 2004, for full details of the questionnaire and its methodology). The unit of analysis is the organisation and the respondent is the highest-ranking corporate officer in charge of HRM. The 2003 questionnaire was developed using an iterative process between network members and based on previous experience of running survey rounds since 1990.

Respondents in each country were identified via the use of a database of senior HR managers in public and private sector organisations. For the purpose of this study, only North American owned private sector multinational organisations in the UK, Australia, Germany, Sweden, Denmark, The Netherlands, USA and Canada were included. This data set comprised of a total of 540 organisations. The overall data was approximately representative for the population of each country in terms of industry sector and organisation size.

\section{INSERT TABLE 1 HERE}

For the purpose of the analysis, firms were grouped according to whether they were located in a liberal market economy (UK and Australia), a co-ordinated market economy (Denmark, Germany, Netherlands and Sweden) or in the home environment, namely North America.

The 2003 Cranet survey (2003 data) identifies companies' ownership by continent rather than individual country, therefore we were only able to access data for North American (i.e. Canada and USA combined) owned companies. There are a number of factors that make this feasible. Firstly, in earlier iterations of the Cranet survey when ownership was identified by individual country, the number of Canadian subsidiaries was small in comparison with USA foreign affiliates. For example, in the 1999 survey only 18 responses were received from Canadian owned countries located out of Canada (out of a total of 9394 responses). Secondly, 
if the expected differences of the Canadian institutional context to CMEs are smaller than those differences expected between the USA context and CMEs, identifying divergences of North American MNCs in co-ordinated host environments will be harder than just using USA MNCs. Thus, our approach may represent more of an 'acid test'.

\section{Measures and analyses}

The dependent variable was location as whether the firm was located in a liberal market economy, a co-ordinated market economy or North America (1, 2 or 3).

Arising from our earlier taxonomy of HRM as a multifaceted construct, we developed measures of HRM policy and practice that tapped all of the domains described above. These were constructed by combining responses on a series of related variables into an index. This follows the precedent of previous literature using Cranet data, for example Croucher et al., 2006; Fenton-O’Creevy et al., 2008). The variables employed were as follows:

Strategic HRM This is an index consisting of responses to eight items from the Cranet survey and is designed to assess how 'strategic' the role of the HR department within the organisation is. The eight questions are:

- Does the head of the personnel/HR department have a place on the main Board of Directors or equivalent? $(1=$ yes, $0=$ no $)$.

- At what stage is the person responsible for personnel/HR involved in the development of business strategy? (a four-point scale: consultation from the outset $=4$, not consulted $=1$.).

- Does your organisation have a Personnel/HRM strategy? $(2=$ yes, written, 1 = yes, unwritten, $0=$ no). 
- Who has primary responsibility for major policy decisions in the following issues: pay and benefits, recruitment and selection, training and development, industrial relations, workforce expansion/reduction? (A four-point scale: line management $=1$, line management in consultation with $\mathrm{HR}=2, \mathrm{HR}$ in consultation with line management $=$ 3, HR department $=4$ ).

The sum of the responses to the above eight questions was used to form an index that ranged from 1 (low degree of strategic HRM) to 27 (high degree of strategic HRM). The reliability of this index as measured by Cronbach's alpha was 0.68 .

Selection sophistication This was a composite measure of which methods were used to select management, professional/technical, clerical and manual employees. The methods included were panel interviews, one-to-one interviews, application forms, psychometric tests, assessment centres and references. A 24-point scale was created with 24 indicating that the firm used all six methods across all four levels and zero suggesting that none of the methods was used for any level. The reliability of this index as measured by Cronbach's alpha was 0.77 .

Investment in training This was measured by a single item where respondents were asked to indicate the actual proportion of their annual payroll bill that was spent on training.

Individualised rewards This was a composite measure of whether management, professional/technical, clerical and manual employees were offered variable pay based upon individual performance. A four-point scale was created with four indicating that the firm offered variable pay based on individual performance to all four levels and zero indicating that none of the four levels were offered this. The reliability of this index as measured by Cronbach's alpha was 0.80 .

Diversity programmes An index was created to measure whether the company had action programmes to cover minority ethnics, older workers, people with disabilities and women. A 
score of four would indicate that the firm offered programmes for all four of these categories while zero would indicate that the firm offered programmes for none of these categories. The reliability of this index as measured by Cronbach's alpha was 0.79 .

Trade union recognition This was a single item asking respondents whether the firm recognised trade unions for the purpose of collective bargaining $(1=$ yes, $0=$ no $)$.

Formal consultation A single item was used where respondents were asked whether the firm had a joint consultative committee or works council $(1=$ yes, $0=$ no $)$.

Direct Communication This was a composite measure of whether firms used verbal, written or electronic methods to communicate directly to employees. A four-point scale was created with three indicating that all three methods were used and zero indicating that none of the three were used. The reliability of this index as measured by Cronbach's alpha was 0.65.

Indirect communication A single item measure was utilised asking respondents whether the firm had a representative staff body for communicating with employees $(1=$ yes, $0=$ no).

Briefing strategy This was a composite measure of whether organisations briefed clerical and manual employees on issues of business strategy, financial performance and organisation of work. A seven-point scale was created with six indicating the briefing of both clerical and manual employees on all three issues and zero indicating no briefing of either category on any of the issues. The reliability of this index as measured by Cronbach's alpha was 0.76 .

The controls included:

Industry sector This was a dichotomous variable distinguishing manufacturing (1) and services (2).

Organisation size This was operationalised as the $\log (10)$ of the number of employees. Age of organisation This was operationalised as the $\log (10)$ of the number of years since the organisation was founded. 


\section{Results}

Prior to examining our research questions, a bivariate correlation analysis of the predictor variables was conducted. The results of this analysis are shown in table 2.

\section{INSERT TABLE 2 HERE}

It can be seen from the above table that, while there were some correlations between variables, these were not large enough to indicate multicollinearity.

In order to examine the research questions, a MANOVA was conducted in order to determine the differences between North American owned companies located in North America, in liberal market economies outside of North America (LME) and in co-ordinated market economies (CME). All variables were standardized to $\mathrm{z}$ scores prior to this analysis. The overall model was highly significant (Wilks Lambda $=0.653, \mathrm{~F}=3.462, \mathrm{p}<0.01$ ). We can therefore go on to examine the univariate $\mathrm{F}$ values from the MANOVA.

\section{INSERT TABLE 3 HERE}

The MANOVA demonstrated that there were some significant differences between North American owned MNCs located in host LMEs, host CMEs or located at home in North America. North American MNCs in the three locations were significantly different in terms 
of their selection sophistication, diversity programmes, trade union recognition, formal consultation and briefing strategy. To answer our first research question therefore, this finding suggests that North American owned MNCs located in CMEs are indeed different to those located in LMEs or in North America itself. Post-hoc Tukey's tests were then carried out for those variables with significant $\mathrm{F}$ values (also shown in table 3).

An examination of the means in the three locations showed that selection sophistication was highest in LMEs, followed by North America and then lowest in CMEs. A post-hoc Tukey's HSD showed that the difference between selection sophistication in North American MNCs in CMEs and LMEs was statistically significant $(\mathrm{p}<0.01)$. Diversity programmes were more common in North American MNCs located in North America, compared to the similar levels in North American MNCs located in LMEs and CMEs. A post-hoc Tukey's HSD indicated that the difference between MNCs located in North America and LMEs was significant $(p<0.01)$, as was the difference between MNCs located in North America and CMEs $(p<0.01)$. Trade union recognition was higher in North American MNCs located in CMEs, compared to those located in LMEs or in North America. The difference between North American MNCs in LMEs and CMES $(\mathrm{p}<0.01)$ and the difference between North American MNCs in CMEs and in North America $(\mathrm{p}<0.05)$ were significant according to a post-hoc Tukey's HSD $(\mathrm{p}<0.01)$. Formal Consultation was also more common in North American MNCs located in CMEs compared to those located in LMEs or North America. A post-hoc Tukey's HSD showed that these differences were highly significant $(\mathrm{p}<0.01)$. Briefing strategy was highest in North American MNCs in CMEs, followed by those in LMEs and then North America. The difference between briefing strategy in North American MNCs in CMEs or LMEs compared to those in North America was significant according to the post-hoc Tukey's HSD $(\mathrm{p}<0.05)$. 
Overall our results showed that, half of the HR areas examined in North American MNCs are different, according to whether they are operating in a LME, CME or in North America itself. Specifically, we have seen significant differences in terms of selection sophistication, trade union recognition and formal consultation between North American companies in LMEs and CMEs, and for other HR areas, namely briefing strategy and diversity programmes, between those MNCs operating in North America or outside North America (regardless of whether they are located in an LME or CME) and can therefore answer our first research question positively.

With reference to our second research question, the results also suggested that North American MNCs in North America are more similar to North American MNCs in LMEs than to those in CMEs for our variables of selection sophistication, trade union recognition, formal consultation and briefing strategy. However, for diversity programmes, North American MNCs in North America were significantly different to both those operating in LMEs and CMEs.

\section{Discussion}

The enormous significance of multinational companies, most especially North American owned MNCs, in the global economy is without question. In Dicken's (2003: 197) words: "more than any other single institution, the transnational corporation...has come to be regarded as the primary shaper of the contemporary global economy". The MNC is often viewed as the vehicle by which dominant HR policies and practices are transported across 
national boundaries. Against this however, Guest and Hoque (1996: 50) have noted that "even in an increasingly global economy, we find persistent variations in the approaches to the management of human resources". And while often USA MNCs are scrutinised, there is a tendency for MNCs from other countries - such as from Germany, the UK or Japan - to transfer parts of their HR approaches internationally (Dickmann, 2003; Geppert, Matten and Williams, 2003; Müller, 1998). A critical question in this respect therefore is whether human resource practices that reflect the country of ownership are imposed on the MNCs subsidiary operating in different host locations? We have explored this question through our examination of HRM practices in North American MNCs in different locations.

Much of the landscape of HRM in MNCs is relatively uncharted and the role of institutional context is under-researched. It is asserted that the institutional environment can strongly influence the development of formal structures in an organization, often more profoundly than market pressures, resulting in the necessity to localize and adapt practices in order to operate successfully within the host institutional environment (Tregaskis et al., 2001), but cross cultural, empirical evidence on this matter is relatively scarce.

This paper adds to the available robust, cross-national evidence. Drawing upon the varieties of capitalism argument as our contextual framework for distinguishing liberal and coordinated market economies, we have sought to determine the likelihood of, and limits to, the standardisation of HRM practices among North American MNCs operating in diverse host locations. We isolated these MNCs operating in a diverse set of locations in order to test whether there were distinctive patters of standardisation and localisation being pursued, depending on whether these North American owned MNCs were operating in the home environment or abroad in liberal or co-ordinated market economies. 
Our results, in combination, point to the important of context and the proximity or distance between the home and host institutional environment as factors that hold important explanatory power in determining the likely pattern of HRM policies and practices pursued. In this respect, our empirical effort further explicates the value of the contextual paradigm in international comparative HRM research and its approach to searching for an overall understanding of what is contextually unique and why. In our topic area, it is focused on understanding what is different between and within HRM in various contexts. Thus, from our analysis, sophisticated selection as the preferred approach to employee resourcing once again emerged as significant, being highest among MNCs operating in LMEs and in MNCs operating at home in North America. Given the preference for a multifaceted approach to selection in the home location, the transfer of this approach to LMEs is to be expected and the deployment of a range of selection tools where there are few language, cultural or institutional barriers can be expected.

As predicted the deployment of diversity programmes was significant, being most prevalent among MNCs operating at home. The North American literature on the competitive benefits and HR opportunity of diversity is growing (Cox and Blake, 1991; Richard, 2000). Diversity is a typical example of an issue that has received much more attention in both the legal and business HR arena on the other side of the Atlantic than it ever has in Europe (Ferner et al., 2006).

In line with our expectations, trade union recognition was highly significant in our model, with CME location emerging as distinctive from both LME and home location. CMEs display a characteristic collectivism, which is expressed as the provision for union recognition and 
the right to bargaining. This sits in contrast to the North American context where the social and economic environment has been described as hostile to unionism and to many traditional union practices and policies (Blanchflower and Freeman, 1992). Gooderham et al. (2004: 20) refer to the emergence of USA HRM as a new model of management, less compatible with unionisation than the old and purposefully designed to remove the rigidities intrinsic in the mass production system. Therefore a rather constant thread in research programmes in the USA has been the link between HRM practices and union avoidance.

Allied to the trade union recognition issue, while indirect communication was not significant in our model, it was nearing significance $(\mathrm{p}=0.07)$, being highest in CMEs, when compared with LMEs or home location. Indirect communication was also highly prevalent in LME operations, in comparison to the home location. Similarly, formal consultation was highest in CMEs, followed by LMEs and lowest in the home location, confirming, once again, the significant of host location regulatory frameworks for determining such consultation. In this respect Morley et al. (2000) have argued that there is clear evidence that organisations in European CMEs are going beyond mere statements about their employees being their major asset, to developing and increasing the amount of communication and consultation in which they involve those employees.

Overall therefore, in our analysis contextual determinants can be viewed as important explanatory factors governing the likely pursuit of standardised or more localised HR practices. Where institutional distance is low, the host institutional environment may be read as permissive of headquarter derived practices, with the result that standardisation is the likely preferred approach among the North American owned MNCs studied. By contrast, where the host environment is viewed as being more distant from the home, with high 
expectations of conformance to the regulatory framework, elements of localisation will be engaged in. This is especially evident in the area of trade union recognition for the purposes of collective bargaining, consultation provisions and collective, rather than purely direct individualised communication provision, where the pattern in institutionally distant CMEs is distinctive from that observed in the home environment and the more proximate LME environment.

\section{Conclusion}

Several contributors have previously argued for the critical role played by the context and the necessity to give expression to this in conceiving our intercultural research models and in explaining differences in the extent to which MNCs can and will pursue localized, rather than standardized, HRM practices (Carr and Pudelko, 2006; Von Glinow et al., 2002; Geppert, Matten and Williams, 2003). Our evidence adds further weight to the likely influence of context in this regard. Employing a national business systems lens as a theoretical framework for capturing the degree of institutionalised distance between the home and host environment, our empirical test sought to establish the significance of high or low institutional distance in accounting for the likelihood of standardisation or localisation in HRM policy and practice among these MNCs when operating abroad. On the institutional proximity or distance from the North American home context as a determinant of standardisation or localisation, we conclude that this is significant in explaining the likely pattern of HR policies and practices pursued. In this way, our evidence here lends support to the argument that HRM is not a universal concept, but rather remains a socially constructed, institutionally derived phenomenon with manifest differences in the way it is conceptualized and conducted (Geppert, Matten and Williams, 2003). 
One of the contributions of this research is that it allows a wide perspective on the varieties of capitalism literature and the degrees of freedom that MNCs have in shaping their HRM strategies, policies and practices. This field is dominated by qualitative, case study based contributions which are extended through our quantitative work. Using the most recent 2003 Cranet data set also allowed us to explore a wide range of countries using a sophisticated set of indicators. Thus, the basis for generalisations based on our findings is stronger, especially given that the large number of Canadian MNCs within the sample meant that we conducted what is in fact an analysis where it would be more difficult to gain significant differences due to HRM in USA MNCs being more distinct from CMEs than that of USA MNCs. The influence of the institutional environment does not, however, mean that cross-national standardisation and knowledge transfer is impossible. It serves to remind us that there are diverse degrees of institutional freedom and that desirability and feasibility of international convergence may diverge. It allows us to reflect on the desirability of institutional cohesion in contrast to innovation from other national business systems and organisational HR configurations. Moreover, it gives valuable insights to HR strategists and practitioners on the requisite complexity of HR approaches in their organisations' strive for international efficiency, local responsiveness and worldwide innovativeness (Dickmann et al., in press 2009).

Significant among the forces at play here are idiosyncratic institutionalised elements derived from inter alia national, cultural and legislation, State intervention and organizational level trade union involvement and participation and the requirement for consultation, dialogue and communication between the social partners. The combination of these forces creates a unique 
contextual landscape, the significance of which the MNC must judge when deciding on its preferred approach to HRM in that host location.

This study is not without its limitations. The use of single source data is not ideal as it may allow bias into our research process. However, we have attempted to overcome these effects by asking about the existence of actual HRM policies and practices, rather than more subjective questions. In addition, while our sample is approximately representative of the population in terms of industry sector and organisation size, we have not controlled for these factors. We have also asked respondents to indicate their general use of particular practices, for example selection methods, across occupational groups and levels. It may be that differences exist between different types of organisations and occupational roles. However, this study still provides a valid and interesting initial investigation of the relationship between location and the localisation or otherwise of HR practices. Further research should examine the impact of the nature of the organisation or role on this relationship.

Clearly more research into the national business system differences in host and home environments and the extent of feasible learning as well as the degrees of HR freedom can become an important source for key institutional and organisational decision-makers. These new insights can provide a linchpin for determining the likelihood of success or failure in, and the desirability of, transferring and standardising practices in the HRM arena.

\section{References}

Almond, P., Edwards, T., Colling, T., Ferner, A., Gunnigle, P., Müller-Camen, M., Quintanilla, J., and Wächter, H., (2005) 'Unravelling Home and Host Country Effects: An 
Investigation of the HR Policies of an American Multinational in Four European Countries', Industrial Relations, 44(2): 276-306.

Bartlett, C. and Ghoshal, S. (1989) Managing Across Borders. London: Hutchinson.

Beaumont, P. (1992) 'The US Human Resource Management Literature: A Review'. In Salaman, G. (ed.) Human Resource Strategies. London: Sage.

Beer, M., Spector, B., Laurence, P., Mills, D. and Walten, R. (1985) Human Resource Management: A General Manager's Perspective. New York: Free Press.

Bélanger, J., Harvey, P-A., Jalette, P., Lévesque, C. and Murray, G. (2006) 'Employment Practices in Multinational Companies in Canada: Building Organizational Capabilities \& Institutions for Innovation'. Report of the Interuniversity Research Centre on Globalization and Work.

Birkinshaw, J. and Fry, N. (1998) 'Subsidiary Initiatives to Develop New Markets', Sloan Management Review, 39(3): 51-62.

Blanchflower, D. and Freeman, R. (1992) 'Unionism in the United States and Other Advanced OECD Countries', Industrial Relations, 31(1): 56-79.

Block, R. (2006) 'Industrial Relations in the United States and Canada'. In Morley, M., Gunnigle, P. and Collings, D. (eds) Global Industrial Relations. London: Routledge: pp. 2552.

Bonache, J. and Dickmann, M. (2008) 'The Transfer of Strategic HR Know-How in MNCs: Mechanisms, Barriers and Initiatives'. In Dickmann, M., Brewster, C. and Sparrow, P. (eds) 
International Human Resource Management - The European Perspective. London: Routledge, (in press).

Brewster, C., Mayrhofer, W. and Morley, M. (eds) (2000) New Challenges for European Human Resource Management, London: Macmillan and New York: St. Martin's.

Brewster, C., Mayrhofer, W. and Morley, M. (eds) (2004) Human Resource Management in Europe: Evidence of Convergence? Oxford: Butterworth-Heinemann.

Carr, C. and Pudelko, M. (2006) 'Convergence of Management Practices in Strategy, Finance and HRM Between the USA, Japan and Germany', International Journal of Cross Cultural Management, 6(1): 75-100.

Colling, T. and Clark, I. (2002) 'Looking for 'Americanness': Home-Country, Sector and Firm Effects on Employment Systems in an Engineering Services Company', European Journal of Industrial Relations, 8(3): 301-324.

Cox, T. and Blake, S. (1991) 'Managing Cultural Diversity: Implications for Organizational Competitiveness', Academy of Management Review, 5(3): 45-56.

Croucher, R., Gooderham, P. and Parry, E. (2006) 'The Antecedents of Direct Communication in British and Danish Firms: Strategic HRM or Union Pressure?', European Journal of Industrial Relations, 12(3): 267-286.

Cutcher-Gershenfeld, J., Nitta, M., and Betty, J. (1998) Knowledge-Driven Work: Unexpected Lessons from Japanese and United States Work Practices. Oxford: Oxford University Press. 
Dicken, P. (2003) Global Shift: Reshaping the Global Economic Map in the $21^{\text {st }}$ Century, $4^{\text {th }}$ Edition. London: Sage.

Dickmann, M. (2003) 'Implementing German HRM Abroad: Desired, Feasible, Successful?’, International Journal of Human Resource Management, 14(2): 265-283.

Dickmann, M. and Müller-Camen, M. (2006) 'A Typology of International Human Resource Management Strategies and Processes', International Journal of Human Resource Management, 17: 580-601.

Dickmann, M., Müller-Camen, M. and Kelliher, C. (2009, in press) 'Striving for Transnational Human Resource Management - Principles and Practice', Personnel Review, $38(1)$

DiMaggio, P. J. and Powell W. W. (1991) 'The Iron Cage Revisited: Institutional Isomorphism and Collective Rationality in Organizational Fields'. In New Institutionalism in Organizational Analysis. London: University of Chicago Press.

Egan, M.-L. and Bendick, M. (2003) 'Workforce Diversity Initiatives of US Multinational Corporations in Europe', Thunderbird International Review, 45(6): 701-727.

Fenton-O'Creevy, M., Gooderham, P. and Nordhaug, O. (2008) 'Human Resource Management in US Subsidiaries in Europe and Australia: Centralisation or Autonomy?' Journal of International Business Studies, 39(1): 151-167.

Ferner, A. (1997) 'Country of Origin Effects and HRM in Multinational Companies', Human Resource Management Journal, 7 (1): 19-36. 
Ferner, A. and Edwards, P. (1995) 'Power and Diffusion of Organizational Change within Multinational Enterprises', European Journal of Industrial Relations, 1(2): 229-257.

Ferner, A. and Quintanilla, J. (1998) 'Multinationals, National Business Systems and HRM: The Enduring Influence of National Identity or a Process of 'Anglo-Saxonization', International Journal of Human Resource Management, 9(4): 710-731.

Ferner, A., Almond, P., Clark, I. Colling, T., Edwards, T. et al (2004) 'The Dynamics of Central Control and Subsidiary Anatomy in the Management of Human Resources: Case Study Evidence from US MNCs in the UK', Organization Studies, 25(3): 363-391.

Ferner, A., Almond, P. and Colling, T. (2005) 'Institutional Theory and the Cross-National Transfer of Employment Policy: The Case of 'Workforce Diversity' in US Multinationals', Journal of International Business Studies, 36: 304-321.

Ferner, A., Morley, M., Müller-Camen, M. and Susaeta, L. (2006) 'Workforce Diversity Policies'. In Almond, P. and Ferner, A. (eds), American Multinationals in Europe: Managing Employment Relations Across National Borders. Oxford: Oxford University Press, pp. 146171.

Fombrun, C., Tichy, N. and Devanna, M. (1984) Strategic Human Resource Management. Wiley: New York.

Geppert, M., Matten, D. and Williams, K. (2003) 'Change Management in MNCs: How Global Convergence Intertwines with National Diversities', Human Relations, 56(7): 807838. 
Geppert, M., Williams, K. and Matten, D. (2003) 'The Social Construction of Contextual Rationalities in MNCs: An Anglo-German Comparison of Subsidiary Choice', Journal of Management Studies, 40(3): 617-641.

Giardini, A., Kabst, R. and Müller-Camen, M. (2005) 'HRM in the German Business System', Management Revue, 16(1): 63-80.

Gooderham, P., Morley, M., Brewster, C. and Mayrhofer, W. (2004) 'Human Resource Management: A Universal Concept?'. In Brewster, C., Mayrhofer, W. and Morley, M. (eds), European Human Resource Management: Evidence of Convergence? Oxford: ButterworthHeinemann, pp. 1-26.

Gooderham, P., Nordhaug, O. and Ringdal, K. (1998) 'When in Rome, do they do as the Romans? HRM Practices of US subsidiaries in Europe', Management International Review, 38: $47-64$.

Guest, D. (1990) 'Human Resource Management and the American Dream', Journal of Management Studies, 27: 377-97.

Guest, D. and Hoque, K. (1996) 'National Ownership and HR Practices in UK Greenfield Sites', Human Resource Management Journal, 6(4): 50-74.

Gunnigle, P., Murphy, K., Cleveland, J., Heraty, N. and Morley, M. (2001) 'Human Resource Management Practices of U.S.-Owned Multinational Corporations in Europe: Standardization versus Localization?', Advances in International Management, 14: 259-284.

Gupta, A. and Govindarajan V. (2000) 'Knowledge Flows within Multinational Corporations', Strategic Management Journal, 21(4): 473-496. 
Hall, P.A. and Soskice, D. (eds) (2001) Varieties of Capitalism: The Institutional Foundations of Comparative Advantage. Oxford: Oxford University Press.

Jacoby, S. (2005) The Embedded Corporation: Corporate Governance and Employment Relations in Japan and the United States. Princeton: Princeton University Press.

Kalleberg, A., Knoke, D., Marsden, P., and Spaeth, J. (eds) (1996) Organizations in America: Analysing their Structures and Human Resource Practices. Thousand Oaks: Sage.

Kostova, T. (1999) 'Transnational Transfer of Strategic Organisational Practices: A Contextual Perspective', Academy of Management Review, 24(2): 308-324.

Kostova, T. and Roth, K. (2002) 'Adoption of an Organizational Practice by Subsidiaries of Multinational Corporations: Institutional and Relational Effects', Academy of Management Journal, 45(1) 215-233.

Mayrhofer, W., Brewster, C. and Morley, M. (2000) 'The Concept of Strategic European Human Resource Management'. In Brewster, C., Mayrhofer, W. and Morley, M. (eds) New Challenges for European Human Resource Management. London: Macmillan, pp. 3-37.

Mayrhofer, W., Müller-Camen, M., Ledolter, J., Strunk, G. and Erten, C. (2002) 'The Diffusion of Management Concepts in Europe - Conceptual Considerations and Longitudinal Analysis', Journal of Cross-Cultural Competence and Management, 3: 315-349.

Morley, M., Gunnigle, P., O’Sullivan, M. and Collings, D. (2006) 'New Directions in the Roles and Responsibilities of the HRM Function', Personnel Review, 35 (6): 609-617.

Morley, M. and Heraty, N. (2004) 'International Assignments and Global Careers'. Thunderbird International Business Review, 46(6): 633-646. 
Morley, M., Mayrhofer, W. and Brewster, C. (2000) 'Communication in Organizations: Dialogue and Impact'. In Brewster, C. and Holt Larsen, H. (eds) Human Resource Management in Northern Europe: Trends, Dilemmas and Strategy. Oxford: Blackwell, pp. 147-170.

Müller, M. (1998) 'Human Resource and Industrial Relations Practices of UK and US Multinationals in Germany', International Journal of Human Resource Management, 9(4): 732-749.

Noble, C. (1997) 'The Management of Training in Multinational Corporations: Comparative Case Studies', Journal of European Industrial Training', 21(Feb/March): 102-110.

Poutsma, E., Ligthart, P. and Schouteten, R. (2005) 'Employee Share Schemes in Europe: The Influence of US Multinationals', Management Revue, 16(1): 99-122.

Pudelko, M. (2006) 'A comparison of HRM systems in the USA, Japan and Germany in their Socio-Economic Context', Human Resource Management Journal, 16(2): 123-153.

Richard, O. (2000) Racial Diversity, Business Strategy, and Firm Performance: A ResourceBased View, Academy of Management Journal, 43: 164-177.

Rosenzweig, P. and Nohria, N. (1994) Influences on human resource management practices in multinational corporations, Journal of International Business Studies, 25(2): 229-51.

Schuler, R. S. and Jackson, S. E. (1987) 'Linking Competitive Strategies with Human Resource Management Practices', Academy of Management Executive, 1(3): 207-219. 
Schuler, R. S. and Jackson, S. E. (2005) 'A Quarter-Century Review of Human Resource Management in the U.S.: The Growth in Importance of the International Perspective', Management Review, 16(1): 11-35.

Singe, I. and Croucher, R. (2005) 'US Multi-Nationals and the German Industrial Relations System, Management Revue, 16(1): 123-137.

Strauss, G. (2001) 'HRM in the USA: Correcting some British Impressions', International Journal of Human Resource Management, 12(6): 873-97.

Szulanski, G. (1996) 'Exploring Internal Stickiness: Impediments to the Transfer of Best Practice within the Firm', Strategic Management Journal, 17(Winter Special Issue): 27-43.

Templer, A., Hofmeyr, K. and Rall, J. (1997) 'An International Comparison of Human Resource Management Objectives and Activities', The International Journal of Human Resource Management, 8(4): 550-562.

Tregaskis, O., Heraty, N. and Morley, M. (2001) 'HRD in Multinationals: the Global/Local Mix', Human Resource Management Journal, 11(2): 34-56.

Vitols, S., Casper, S., Soskice, D. and Woolcock, S. (1997) Corporate Governance in Large British and German Companies. London: Anglo-German Foundation for the Study of Industrial Society. 
Von Glinow, M.A., Drost, E. A. and Teagarden, M.B. (2002) 'Converging on IHRM Best Practices: Lessons Learned from a Globally Distributed Consortium on Theory and Practice', Human Resource Management, 41(1): 123-140.

Whitley, R. (1999) Divergent Capitalims: The Social Structuring and Change of Business Systems. Oxford University Press: Oxford. 
Table 1 Number of responses from North American owned multinationals by country

\begin{tabular}{lc}
\hline Country & No. responses \\
\hline Australia & 20 \\
Canada & 188 \\
Denmark & 33 \\
Germany & 20 \\
Netherlands & 17 \\
Sweden & 24 \\
United Kingdom & 125 \\
USA & 113 \\
\hline
\end{tabular}


Table 2 Descriptives and bivariate correlations

\begin{tabular}{|c|c|c|c|c|c|c|c|c|c|c|c|c|c|c|c|}
\hline Variable & Mean & $S D$ & $\begin{array}{l}\text { Strategic } \\
H R\end{array}$ & $\begin{array}{l}\text { Selec- } \\
\text { tion }\end{array}$ & $\begin{array}{l}\text { Train- } \\
\text { ing }\end{array}$ & Pay & Diversity & $\begin{array}{l}\text { Union } \\
\text { recog- } \\
\text { nition }\end{array}$ & $\begin{array}{l}\text { Consul } \\
\text {-tation }\end{array}$ & $\begin{array}{l}\text { Direct } \\
\text { Comm }\end{array}$ & $\begin{array}{l}\text { Indirec } \\
t \text { Comm }\end{array}$ & $\begin{array}{l}\text { Brief- } \\
\text { ing }\end{array}$ & $\begin{array}{l}\text { Indus- } \\
\text { try }\end{array}$ & $\begin{array}{l}\text { Size } \\
\text { (log) }\end{array}$ & $\begin{array}{l}\text { Age } \\
\text { (log) }\end{array}$ \\
\hline Strategic HR & 18.15 & 6.37 & & $-0.15 * *$ & 0.04 & $0.07 * *$ & $0.12 * *$ & $-0.51^{*}$ & 0.04 & $0.06^{*}$ & 0.03 & $0.16^{* *}$ & $0.07 * *$ & $0.11^{* *}$ & -0.01 \\
\hline Selection & 10.18 & 4.21 & $-0.15^{* *}$ & & -0.03 & $0.05^{*}$ & $0.06 * *$ & $-0.05 *$ & -0.04 & $0.07 * *$ & 0.03 & $0.26^{* *}$ & -0.01 & $0.04 * *$ & 0.02 \\
\hline Training & 3.55 & 3.99 & 0.04 & -0.03 & & 0.02 & $0.14 * *$ & $-0.09 *$ & $-0.08 *$ & -0.01 & 0.04 & 0.03 & $0.12 * *$ & -0.03 & -0.02 \\
\hline Pay & 1.17 & 1.40 & $0.07 * *$ & $0.05^{*}$ & 0.02 & & $0.08 * *$ & 0.01 & $0.05 * *$ & $0.07 * *$ & 0.04 & $0.05^{*}$ & 0.04 & $0.17 * *$ & 0.03 \\
\hline Diversity & 0.70 & 1.19 & $0.12 * *$ & $0.06^{* *}$ & $0.14 * *$ & $0.08 * *$ & & 0.04 & $0.06 * *$ & $0.05^{*}$ & $0.06^{*}$ & 0.04 & $0.05^{*}$ & $0.17^{*}$ & 0.02 \\
\hline Union recognition & 0.65 & 0.48 & $-0.51^{*}$ & $-0.05^{*}$ & $-0.09 * *$ & 0.01 & 0.04 & & $0.49 * *$ & -0.01 & $0.55^{* *}$ & $0.13 * *$ & $-0.22 *$ & $0.13^{*}$ & $0.09 * *$ \\
\hline Consultation & 0.60 & 0.49 & 0.04 & -0.04 & $-0.08 *$ & $0.05^{* *}$ & $0.06 * *$ & $0.49 * *$ & & 0.02 & $0.62 * *$ & $0.23 * *$ & $-0.22 * *$ & $0.12 * *$ & $0.07 * *$ \\
\hline $\begin{array}{l}\text { Direct } \\
\text { Communication }\end{array}$ & 2.93 & 0.28 & $0.06^{*}$ & $0.07 * *$ & -0.01 & $0.07 * *$ & $0.05^{*}$ & -0.01 & 0.02 & & 0.02 & $0.12 * *$ & $0.06^{* *}$ & $0.10 * *$ & 0.02 \\
\hline $\begin{array}{l}\text { Indirect } \\
\text { Communication }\end{array}$ & 2.42 & 1.13 & 0.03 & 0.03 & -0.04 & 0.04 & $0.06^{*}$ & $0.55^{* *}$ & $0.62 * *$ & 0.02 & & $0.22 * *$ & $-0.22 * *$ & 0.14 & $0.01 * *$ \\
\hline Briefing & 0.70 & 0.46 & $0.16^{* *}$ & $0.26^{* *}$ & 0.03 & $0.05^{*}$ & 0.04 & $0.13 * *$ & $0.23 * *$ & $0.12 * *$ & $0.22 * *$ & & $-0.16^{* *}$ & 0.03 & -0.00 \\
\hline Industry & 1.50 & 0.50 & $0.07 * *$ & -0.01 & $0.12 * *$ & 0.04 & $0.05^{*}$ & $-0.22 * *$ & $-0.22 * *$ & $0.06 * *$ & $-0.22 * *$ & $-0.16^{* *}$ & & $0.09 * *$ & $-0.11 * *$ \\
\hline Size (log) & 2.71 & 0.57 & $0.11 * *$ & $0.04 * *$ & -0.03 & $0.17 * *$ & $0.17^{*}$ & $0.13 * *$ & $0.12 * *$ & $0.10 * *$ & 0.14 & 0.03 & $0.09 * *$ & & $0.09^{*}$ \\
\hline Age $(\log )$ & 1.61 & 0.45 & -0.01 & 0.02 & -0.02 & 0.03 & 0.02 & $0.09 * *$ & $0.07 * *$ & 0.02 & $0.01 * *$ & -0.00 & $0.11 * *$ & $0.09 *$ & \\
\hline
\end{tabular}


Table 3 Comparison of HR predictors by location (means and Fs from Multiple ANOVA)

\begin{tabular}{|c|c|c|c|c|c|c|c|c|}
\hline Predictor & $\mathrm{n}$ & $\begin{array}{l}\text { North } \\
\text { America } \\
\text { (mean) }\end{array}$ & $\begin{array}{l}\text { LME } \\
\text { (mean) }\end{array}$ & $\begin{array}{l}\text { CME } \\
\text { (mean) }\end{array}$ & $\begin{array}{l}\text { Overall F } \\
\text { (from } \\
\text { MANOV } \\
\text { A) }\end{array}$ & $\begin{array}{c}\text { T1 (NA } \\
\text { vs. LME) }\end{array}$ & $\begin{array}{c}\text { T2 (NA } \\
\text { vs. CME) }\end{array}$ & $\begin{array}{l}\text { T3 (LME } \\
\text { vs. CME) }\end{array}$ \\
\hline Strategic HR & 423 & 5.07 & 5.27 & 5.69 & $2.72 *$ & 0.311 & 0.094 & 0.405 \\
\hline Selection sophistication & 540 & 10.45 & 11.46 & 9.55 & $6.01 * *$ & 0.106 & $0.603^{*}$ & $0.708 * *$ \\
\hline Investment in training & 285 & 4.26 & 3.50 & 3.06 & 1.61 & 0.262 & 0.363 & 0.100 \\
\hline Individualised pay & 409 & 1.28 & 1.05 & 1.46 & 0.12 & 0.090 & 0.060 & 0.030 \\
\hline Diversity programmes & 473 & 1.03 & 0.60 & 0.59 & $9.01 * *$ & $0.578 * *$ & $0.871 * *$ & 0.293 \\
\hline Trade union recognition & 514 & 0.49 & 0.47 & 0.85 & $5.68 * *$ & 0.168 & $0.529 *$ & $0.697 * *$ \\
\hline Formal consultation & 374 & 0.32 & 0.48 & 0.79 & $9.66^{* *}$ & 0.250 & $0.872 * *$ & $0.622 * *$ \\
\hline Direct communication & 502 & 2.94 & 2.93 & 2.97 & 0.78 & 0.196 & 0.009 & 0.205 \\
\hline Indirect communication & 456 & 0.45 & 0.61 & 0.80 & 2.85 & 0.020 & -0.462 & 0.483 \\
\hline Briefing strategy & 540 & 2.79 & 3.72 & 4.07 & $4.30 *$ & $0.461 *$ & $0.489^{*}$ & 0.028 \\
\hline
\end{tabular}

(Note: means are of non-standardised variables)

${ }^{*} \mathrm{p}<0.05 ; * * \mathrm{p}<0.01$

T1, T2 and T3 represent mean difference scores from post hoc Tukey's HSD tests. 